\title{
Advocacy Compromised: How Financial, Organizational and Institutional Factors Shape Advocacy Strategies of Civil Society Organizations
}

\author{
Malin Arvidson $^{1}$ (D) Håkan Johansson ${ }^{1} \cdot$ Roberto Scaramuzzino $^{1}$
}

Published online: 10 August 2017

(C) The Author(s) 2018

\begin{abstract}
Key functions of civil society organizations (CSOs) are to criticize governments and to hold them to account. Recent trends of privatization and contracting out challenge CSOs' opportunities to voice such criticism. The purpose of this article is to analyse whether and why CSOs 'hold back their criticism' of public authorities, and how a compromised advocacy can be linked to financial, organizational and institutional factors. The article draws on an original survey of 2678 Swedish CSOs. The analyses show that certain levels of funding make CSOs more likely to hold back in their criticism, but also organizational and institutional factors play a role. The results identify the importance of distinguishing between objective and subjective factors related to how dependency is framed. It is the felt needs, experiences and perceptions of CSOs themselves that make hem prone to the strategic choice to hold back criticism of public authorities.
\end{abstract}

Keywords Advocacy · Service function · Civil society organizations $\cdot$ Resource dependence $\cdot$ Competition

Update 22 August 2018 The PDF version of this article was reformatted to a larger trim size.

Malin Arvidson

Malin.arvidson@soch.lu.se

Håkan Johansson

Hakan.johansson@soch.lu.se

Roberto Scaramuzzino

Roberto.scaramuzzino@soch.lu.se

1 School of Social Work, Lund University, Box 23, 22100 Lund, Sweden

\section{Introduction}

Key functions of civil society are to criticize government and to advocate on behalf of less powerful groups, but it is not self-evident that these functions will be exercised. In authoritarian regimes, advocacy may be actively counteracted, but also in liberal democracies of today, with trends of privatization and contracting out of public services, civil society organizations' (hereafter CSOs) opportunities and approaches to voicing criticism is challenged. Dependency on public funding and more extensive use of 'gagging clauses' have enhanced governments' ability to steer and control CSOs and their advocacy work. Accountability regimes and increased requests for performance evaluation have furthermore made CSOs more inclined and obliged to adjust their activities and operations according to government agendas.

The implications of government funding in relation to CSOs' advocacy activities are well documented in existing research. We find studies that explore issues of CSO advocacy in relation to theories of resource dependence (Chaves et al. 2004; Schmid et al. 2008), organizational characteristics (Child and Gronbjerg 2007; Garrow and Hasenfeld 2012) and institutional pressure (Scott et al. 2006). A central tenet is that as closeness to the public sector increases, so too does dependence on an influential stakeholder, which leads to a change in CSOs' advocacy strategies. Studies investigate the link between such factors and different aspects of CSO advocacy activities, e.g. the strategy preferred (Onyx et al. 2010; Verschuere and De Corte 2015), the intensity of advocacy activities (Schmid et al. 2008), the aims of advocacy (Balassiano and Chandler 2010; Garrow and Hasenfeld 2012; Mosley 2012; Nicholson-Crotty 2007) as well as the relative influence of advocacy on policy-making (Schmid et al. 2008). 
Few studies have, however, directly engaged with whether organizations admittedly compromise on their strategies for advocacy. Whereas much research addresses if particular governance arrangements inadvertently imply advocacy compromise, we find few examples that look into if CSOs hold back their criticism of governments as a conscious choice. The purpose of this article is thus to analyse whether and why CSOs refrain from taking a critical, scrutinizing role aimed at holding the state and municipalities to account. We argue that holding back criticism' can be viewed as a critical litmus indicator of a change in organizational orientation and their level of (in)dependence. It constitutes a significant sign of a change from a situation where organizations can be investigative and critical without jeopardizing good relations with and funding from statutory counterparts, to a situation where the organizations' independence is undermined, its advocacy role compromised and potentially also their democratic function to represent citizens against governments questioned.

The article furthermore analyses the interplay between sets of factors, i.e. financial, organizational and institutional factors and how such factors relate to the choice of CSOs to refrain from criticizing government. While previous research has recognized the significance of each of these, it has generally treated them in isolation and neglected to explore the possible interplay between the types of factors and the implications an integrated approach can have for theorizing the field. The article thus seeks to outline an integrated understanding of how resource dependency, organizational identity and institutional context together can explain when organizations make a strategic choice to compromise on advocacy, defined as a critical voice function.

The empirical data used are based on a large sample of Swedish CSOs (6180 CSOs), mainly active in the social welfare area. Although the study is conducted in the particular context of Sweden, we argue that the analytical conclusions of the study have implications for other contexts with similar changes to relations between CSOs and state agencies.

\section{Holding Back Criticism in Sweden}

The significance of advocacy that involves criticism of government is highly context dependent as in some societies CSOs are expected to do so, by members and the population, perhaps even encouraged by government, while in others it is seen as rebellious and undesirable. This article addresses CSOs' advocacy activities in Sweden. The Swedish context offers a particularly fitting case for studying CSO compromised advocacy as there is an institutionalized tradition that CSOs are encouraged and almost obliged to express criticism against governments and public agencies. To refrain from expressing criticism is in this respect breaking with established norms and role expectations. The possibly unique position of Swedish CSOs becomes clear in international comparisons that tend to conclude that Swedish CSOs appear expressive oriented rather than service oriented (Lundström and Svedberg 2003; Salamon et al. 2004; Trägårdh 2010). This is different from a more service-oriented role taken by CSOs in the USA, the UK and Germany. Swedish CSOs are primarily funded through members' fees and volunteering, and the share of the organizational budget that comes from public funding is relatively low (Salamon et al. 2004). Such a 'Swedish model' has earned strong support in public opinion, including within the civil society sector itself (Olsson et al. 2009; see also Lundström and Svedberg 2003; Lundström and Wijkström 1997). The Swedish system of interest representation is also characterized by 'corporatism', i.e. a system of institutionalized contact, negotiation and joint decision-making between the state and CSOs (Hermansson et al. 1999).

Although Swedish CSOs' 'primary function has been to voice interests and to act as political agents' (Trägårdh 2010: 236), the relationship between state and CSOs is described as dynamic and interactive rather than oppositional and conflictual. This is apparent in the recent Swedish Agreement (2008) between the central government, national CSOs in the social welfare area and the Swedish Association of Local Authorities and Regions, which states that the role of CSOs is that of '... critical reviewers, advocates and opinion makers. They should be able to uphold this role without jeopardizing cooperation with or economic support from the public sector' (p. 22). Swedish CSOs are thus expected to continue to take on a critical, scrutinizing role, aimed at contributing to the development and implementation of public policies.

While statements like these are common in policy documents, this traditional position and role of Swedish CSOs appears to be changing, and so too-potentiallydoes the critical voice function of these organizations (Hartman 2011, Lundström and Wijkström 1995, Johansson 2005, Wijkström and Einarsson 2006, Danielson et al. 2009). A change in structure and conditions of funding suggests that CSOs are increasingly expected to contribute as service providers. Swedish CSOs are traditionally funded through both organizational grants to support the organization itself and project grants that are tied to specific assignments. In recent years, financing based on the production of services on behalf of public organizations has, however, increased (e.g. Danielson et al. 2009, see also Johansson et al. 2015). This is likely to change the dynamics between CSOs and public agencies. At the same 
time, policies aimed at increasing interaction between the non-profit CSOs and the public sector offer new arenas for advocacy (e.g. the abovementioned Agreement), although it is not clear to what extent such arenas feature a diversity of CSOs including advocacy oriented and service oriented. There are also processes that appear to emphasize the importance of more informal, personal contacts and networks (as in more 'liberal' systems as the USA) at the expense of the traditional corporatist forms of arranged consultation (Svallfors 2015).

This suggests a political system where domestic CSOs are expected to fulfil an expressive function and to compromise on the advocacy role to the extent that an organization admits to holding back criticism indicates that the position of the CSO and its relationships with surrounding stakeholders have not only changed significantly, but also that they take on a role that diverges from what is expected from them.

\section{Advocacy Compromised: Towards an Analytical Framework}

Interest in how, why and under what circumstances CSOs exercise advocacy has been a central part of research. Here, advocacy is defined as activities that aim at influencing public opinion and policy processes or regulations, often on behalf of specific groups or interests (Boris and MosherWilliams 1998; Salamon et al. 2004; Mosley 2013a, b, c). Such advocacy activities could range from open demonstrations and letter writing to less visible tactics such as networking and lobbying. Advocacy is then assumed to be directed at the state or local government agencies aimed at promoting new ideas or highlighting inadequacies in the way existing public policies are formulated or implemented.

Research on advocacy as practised by CSOs in a changing institutional context, including new funding arrangements and new fora for policy-related interactions, is developing fast, and this is testimony to the increasingly complex relations between CSOs and public institutions. But as illustrated in Neumayr et al. (2015) thorough review of studies, identifying reliable and coherent indicators for measuring links between CSOs' connections to the public sector and changes in advocacy activities is quite a challenge. Our approach to this issue builds on a review of existing research, which we sort into three different strands of theoretical approaches that seek to analyse advocacy strategies based on distinct sets of factors, i.e. financial, organizational and institutional factors.

One strand of research on advocacy draws on the central relationship between (public) funding and advocacy. Here, we find theories of resource dependency that act as a starting point for exploring how organizations adjust to and adapt their advocacy strategies as dependency becomes stronger (Pfeffer and Salancik 1978). The assumption, that as a result of high government funding CSOs would demonstrate loyalty towards funders and so advocacy activities would be reduced, has continued to influence current debates (Mosley 2012; Schmid et al. 2008; Verschuere and De Corte 2014, 2015).

The relation between 'money' and advocacy is, however, complex. Some studies demonstrate that funding from government can also serve as an incentive for CSOs to engage in advocacy (Child and Gronbjerg 2007; Chaves et al. 2004; Neumayr et al. 2015; Mosley 2012, 2013a, b, c; Scott et al. 2006). Leaders and managers of CSOs will rather than refrain from advocating become motivated to engage in advocacy based on a concern to ascertain continued financial support (Mosley 2012). Much research suggests a correlation between type of funding and the type of strategy deployed. A recent study of Flemish CSOs for instance shows that CSOs with a close relationship with government authorities, including elements of financial dependency, did affect the advocacy strategy preferred as they adopted softer advocacy strategies, such as insider tactics, rather than more confrontational types (Verschuere and De Corte 2015). A study of Australian CSOs shows similar results as CSO managers focus on gaining trust and finding solutions rather than pointing out flaws and openly criticizing authorities (Onyx et al. 2010). The latter study suggests that there is an element of self-censoring involved as CSOs express concern that a confrontational approach would create an oppositional environment (ibid.).

A second strand of research adds organizational characteristics to the analytical dimension and seeks to define what features make organizations more prone to engage in advocacy. We find studies that explore the link between organizational resources or capacity and advocacy. Large organizations do not only have resources, such as employees and skills, but also a greater need for funding, which makes them more predisposed to engage in advocacy (e.g. Child and Gronbjerg 2007). Others stress that organizational characteristics such as degree of professionalization and educational background of managers affect how an organization practises advocacy (Mosley et al. 2012). Research on CSOs and organizational strategies related to accountability practices identify educational background (MacIndoe and Barman 2013), epistemic belief (Hall et al. 2015) and previous experience (Pache and Santos 2010) of managers as key to the strategic paths set out for the organization. It is likely that the influence of manager characteristics on accountability strategies similarly influences advocacy strategies. Still others argue that also age or rather 'the era' in which the organization was formed affects how organizations practice advocacy (Child 
and Gronbjerg 2007). While some CSOs, founded in one era, would prefer open demonstrations aimed at educating the public as well as policy-makers, others that originate in another era would prefer networking and new social media as means of spreading information and raising a critical mass of voices regarding particular topics (Onyx et al. 2010).

However, Garrow and Hasenfeld (2012) suggest that it is the underlying ideology forming the CSO's organizational mission that is a key factor to take into account, rather than attributes of organizations. Their study thus explores the link between organizational identity- 'the moral frame of practice' - and advocacy, underpinning the mission of the organization. CSOs' approach to advocacy thus depends on which moral frame the organization emphasizes. Within this strand of research, we find emphasis on organizational tangibles such as the resources that an organization 'possesses' (e.g. resources, skills, access to networks) as well as organizational identity and the cultural and ideological features of the organization.

A third strand of research addresses how and what institutional context may affect CSOs' advocacy strategies, and Mosley (2011) argues that we must explore "what elements of the human service environment make the conditions of their advocacy involvement different than other advocacy organizations' (p. 438). Such institutional environment includes both structural and normative, cultural factors, such as formal platforms for deliberation, the nature and qualities of relations between stakeholders and expectations regarding advocacy (Garrow and Hasenfeld 2012). Scott et al. (2006) highlight that such an institutional context may be characterized by consensus or conflicts regarding, e.g. how to define social problems and suitable interventions. Overall, CSOs tend to be more willing to be politically active in environments characterized by consensus, where they find more political allies (Nicholson-Crotty 2007) which suggests that it is crucial to assess the structural and political context in which advocacy is practiced. Furthermore, an institutional context that favours competition for government contracts may enhance the effect of dependence on government funding (Hasenfeld and Garrow 2012). With increased competition, the power of market forces becomes more and more pronounced for CSOs with, potentially, the dual effect of CSOs becoming increasingly anxious not to upset relations through challenging advocacy tactics (a strategic choice) and CSOs being subject to organizational mainstreaming according to market logics (isomorphism). As a result, advocacy efforts become 'marginal, limited, and narrowly focused' (ibid: 308). Consequently, as we consider the overall dynamics of a field, and not only the relationship to a specific stakeholder, organizations may feel more or less hesitant to voice opposition or to act in a confrontational manner depending on political climate and level of competition over government contracts. Although a particular setting may offer a forum and incentives for CSOs to voice the interests and concerns of user groups, this does not necessarily mean there is a cognitive space to do so. We can note that two sets of factors converge here: organizational characteristics and the context in which they operate. This makes this aspect of advocacy strategies particularly complex to explore.

These three strands of research provide us with tools to analyse CSOs' advocacy activities and strategies. Taking us to the 'output side' of the equation, we need to carefully address both types and aims of advocacy activities to gain a fuller understanding of the potential link to financial, organizational and institutional factors. Useful distinctions are made between indirect and direct advocacy strategies, and between soft and more confrontational tactics (Binderkrantz 2005; Beyers 2004; Dür and Mateo 2013; Onyx et al. 2010; Verschuere and De Corte 2015). Mosley (2012) distinguishes between insider and outsider tactics when analysing CSO advocacy: while insider tactics are 'carried out with policymakers directly and include activities such as lobbying, providing testimony, and sitting on policy committees' (p. 2), outsider tactics are confrontational in nature and 'include social action, protest and media campaigns' (ibid.). Verschuere and De Corte (2015) also elaborate on insider, outsider and collective strategies, how preferences concerning strategies depend on risk assessment (avoidance of confrontation) and on access to, e.g. networks that allow for insider tactics. Although it is important to identify specific features of advocacy strategies, this does not necessarily support an assessment whether or not advocacy has been compromised. The concern whether changes from confrontational and radical to non-confrontational advocacy strategies (Onyx et al. 2010) also imply that the function of advocacy to assert needs and political demands (Snavely and Desai 2000) is weakened has proven hard to address. For example, studies show that organizations favour 'soft advocacy strategies' aimed at building trust and relations (Verschuere and De Corte 2015; see also Onyx et al. 2010), but whether this should be interpreted as co-optation that involves a bias towards accommodating the interest of public actors and the refraining from taking up a more confrontational position has not been systematically analysed.

While these studies discuss the strategies per se, it is of key concern to problematize the aim of advocacy. Garrow and Hasenfeld (2012), for instance, argue that there is an important distinction between advocacy aimed at social justice and advocacy aimed at ensuring organizational survival and the type of strategies related to them. This distinction approaches the issue whether advocacy as in expressing a critical voice, asserting needs and political 
demands of marginalized and vulnerable constituencies, has been compromised. They suggest that compromise, as in avoiding confrontation, can be made in conjunction with choice of content: social rights for all or securing organizational survival.

Addressing different types of strategies and aims for advocacy is of key importance for a thorough investigation into CSOs' advocacy activities; nonetheless, it is apparent that research so far has not explored holding back criticism as a strategic choice. Hence, we have limited knowledge of the links between 'holding back' as a form of conscious yet compromised advocacy tactic, and how such a strategic choice is related to other factors.

\section{Method and Data}

The present study is based on a quantitative data set from a national survey. The survey was carried out in 2012-2013 as part of the research programme 'Beyond the welfare state: Europeanization of Swedish civil society organizations (EUROCIV)' funded by the Swedish Research Council. The survey questionnaire was sent to 6180 Swedish CSOs resulting in 2791 responses. A total of 740 CSOs were excluded from the sample as they no longer belonged to our population due to incorrect postal addresses and some organizations having ceased to exist, bringing the final response rate to $51.3 \%$.

The survey is based on samples of categories used by Statistics Sweden (SCB) in their register of Swedish organizations (Företagsregistret). The sample frame was constructed in order to include Swedish CSOs one could expect to be engaged in social welfare issues, working with service production and/or interest representation. CSOs involved with social welfare offer a suitable category for exploring possibly compromised advocacy: they have a strong role in representing user groups vis-à-vis public institutions and government, yet they are also subject to changes through increased marketization and the contracting out of social welfare services. In line with this, we included two types of organizations: associations (ideella föreningar) and religious congregations (registrerade trossamfund). Association is the most common organizational form, as it simplifies the way the organization can engage with certain activities (e.g. to carry out limited economic transactions without being taxed). Religious congregations have been chosen as they represent an important part of organized civil society in Sweden, and they are often involved in social welfare activities and public campaigns on behalf of families living in poverty, undocumented migrants and other marginalised groups. The sample for the survey was constructed using a combination of organizational forms and categories based on the types of activities that the organizations were primarily involved in.

The organizational types and activities chosen for the survey were: (1) associations involved in 'social service and care', (2) associations involved in 'interest representation' and (3) religious congregations. ${ }^{1}$ The selection thus excluded associations such as sports, recreational and leisure associations. Among the organizations chosen for the sample, we would expect to find different types of CSOs showing a large variety of resource mobilization patterns and hence different relationships with public authorities. We expect to find organizations that would potentially give a high value to their advocacy function and that are used to voicing opinion and criticism of public authorities and policies.

Through these choices, our total population of CSOs became 80,015 associations, from which the sample (of 6180 CSOs) has been drawn. The population constitutes approximately $40 \%$ of Swedish formally organized civil society ${ }^{2}$ including membership-based organizations and umbrella organizations at all administrative levels, from local to international, with an overrepresentation of organizations involved in social welfare issues and interest representation. In contrast to much previous research on advocacy reviewed for this paper, the CSOs in the sample are not 'most likely' to be dependent on public resources, nor to be service providers on behalf of public authorities. They are a section of Swedish organized civil society involved in advocacy and service production with an emphasis on social welfare issues.

\section{Operationalization}

We have excluded from the original sample those organizations that answered in the negative to a question of whether the organization had any activities during 2012. The following analysis hence builds on 2678 Swedish CSOs.

Based on our review of current research, we have developed three sets of questions to guide our analysis of how compromised advocacy is related to financial, organizational and institutional factors: (1) whether external public resources make CSOs more likely to hold back from

\footnotetext{
${ }^{1}$ Since the groups of our population were quite different in size, we decided to make a stratified sample, in order not to end up with insufficient numbers of cases for some of the smaller categories. Due to the stratified sampling procedure, the data presented in the paper are analysed awarding different weights to the groups in our sample. (For more detailed information about the sampling procedure, see Scaramuzzino \& Wennerhag (2013).)

2 According to Statistics Sweden's calculations, Swedish civil society includes about 217,000 formal organizations (SCB 2010).
} 
criticizing public organizations; (2) whether a particular types of funding arrangements (e.g. linked to specific assignments) make CSOs more likely to hold back criticism; and (3) whether CSOs that experience that their environment is characterized by a high level of competition for public assignments, or that public support is perceived as essential for the organization's survival, are more likely to hold back criticism.

These are operationalized through a dependent variable measuring the extent to which Swedish CSPOs 'hold back criticism of the state and municipalities for the purpose of not jeopardizing economic support'. The question that preceded the statement was formulated in the following way: 'To what extent do the following statements describe your organization in an accurate way?' The respondents could choose between the following alternatives: Very much, Somewhat, Not very much, Not at all, Don't know. We interpret an agreement with this statement as a strategic choice not to voice criticism of public authorities to safeguard present or future economic support.

By asking such a direct question, we expect to be able to identify, in our large sample of CSOs, those organizations that make a specific strategic choice regarding voicing criticism and to identify which factors might explain such a choice. The question does not directly refer to the way in which the criticism is presented (advocacy strategy), nor to what the criticism is about (aim for advocacy). It might actually imply both aspects: choosing a less confrontational strategy and refraining from commenting on sensitive issues, or from expressing any criticism at all. Through such a direct question, we propose an alternative, more direct way of measuring advocacy that goes beyond both 'advocacy strategies' and 'aim of advocacy', which has been the basis of how advocacy is assessed in previous research.

This dependent variable is tested through binary logistic regression against three sets of factors and independent variables. As we cannot assume that the alternatives in the dependent variable are equidistant, for the purpose of this analysis we have transformed it into a dichotomous variable by merging the first two alternatives ('Very much', 'Somewhat') as positive answers (do hold back criticism) and the last two ('Not very much', 'Not at all') as negative answers (do not hold back criticism). While some nuances are lost in the answers, the analysis allows us to see the relative impact of different factors on the organizations' choice of limiting their advocacy role to keep the economic support from municipality and state:

First of all, we address sources of funding for the CSOs' budgets as resource dependency (financial) factors. This is measured through three survey questions. One question listed different sources of funding, asking for each of them if it was 'Very important', 'Quite important', 'Not important' or 'Not a source at all' for the organization. The first two alternatives were categorized as positive and the latter two as negative. The second question asked for an estimate of the share of public funding in the CSO's revenues, offering the following alternatives: 'We do not receive any support', ' $1-25$ ', '26-50', '51-75' and '76-100\%'. The third question asked the CSO to estimate the share of the total public funding received by the organization that was tied to specific purposes, with the same alternatives as in the previous question. Both these variables were recoded into three alternatives: 'no support', ' $1-50$ ' and '51-100\%'. These relate to the first strand of factors, i.e. financial resource dependency factors, as we can interpret a high proportion of and a high importance given public funding as expressions of public resource dependency.

Second, we address service provision, number of employed staff and service orientation as organizational factors. These are measured through three questions. The first question asked the CSO to state if they provide services on behalf of public organizations. The alternatives were 'To a great extent', 'To a fair extent', 'Not especially' and 'Not at all'. The first two alternatives were recoded as positive, while the latter two as negative. The second question asked CSOs about their employed staff. The answers have been divided into three categories: "no employed staff', 'less than five employed staff' and 'five or more employed staff'. The third question asked the CSOs to state the organization's primary orientation following the International Classification of Non-Profit Organizations (ICNPO) (Salamon et al. 2004: 12; SCB 2010: 15). The 12 ICNPO categories were listed as alternatives and then sorted into service oriented and expressive oriented. ${ }^{3}$ These factors relate to the second strand of factors, i.e. organizational factors.

Third, we address the significance of competition and whether the survival of the CSO is at stake as institutional factors. These are measured by three survey questions based on how the CSO interprets its environment: whether the organization's area of activity is characterized by strong competition for public assignments, whether their activities are threatened by competition from private enterprises and whether public assignments are essential for the survival of the organization. The alternatives given were, as in the previous question, 'To a great extent', 'To a fair extent, 'Not especially' and 'Not at all'. They were all recoded in the same way with the first two alternatives interpreted as positive and the latter two as negative. These

\footnotetext{
${ }^{3}$ Cramer's V is often used as an association measure in crosstabulation between nominal variables, giving a value between 0 and +1 , where the value 0 represents no association and the value 1 represents complete association.
} 
factors relate to the third strand of factors, i.e. institutional factors. The survey outline did not allow us to take into account other variables like policy domain, which is a limitation to the analysis.

All questions included a 'Don't know' alternative, and such answers have been recorded as 'missing'. Most independent variables are based on the perceived importance of different sources of funding, of focus of activity and of competition for public assignments. We have also included variables measuring actual (i.e. based on figures) importance such as the percentage of public funding in the budget and the presence of employed staff. We argue that this is an important distinction as it is the perception of possible power asymmetries that might trigger a strategic choice to refrain from expressing criticism of public organizations.

Furthermore, using binary logistic regression structured in different models as a statistical method, we will be able to test which factors are more likely to influence such a strategic choice: funding source, level of dependency on public funding, type of public funding, perception of competition and importance of public support for the survival of the CSO. As our dependent variable is ordinal in nature, we cannot assume equidistance between values. Moreover, we find that the variable's distribution is skewed. Due to the nature of the question and to the particular Swedish context, we argue that the result (a high percentage of negative answers and a low percentage of positive answers) was expected. Consequently, we have chosen to use binary logistic regression. This method does not assume linearity nor normality of distribution in the dependent variable as many other regression methods would. Transforming the variable into a dichotomous one does risk loss of information, in particular with regard to the three positive answers to the question, but it allows us to better analyse the topic of our investigation.

\section{Holding Back Criticism: A Strategic Choice of a Minority of Swedish CSOs}

The advocacy activities explored in this article concern a strategic choice to hold back criticism of the state (and municipalities) for the purpose of not risking economic support. This strategic choice implies a limitation of an ideal advocacy function that would allow for such criticism, without fear of jeopardizing the organization's survival. To hold back criticism could hence be interpreted as of key analytical significance. However, holding back one's criticism must be seen in the context of the extent of the economic support from the state and municipalities in Sweden (given in Table 1), as our dependent variable clearly makes reference to such support in the formulation
Table 1 Importance of state and municipal support for CSOs' budget

\begin{tabular}{lcc}
\hline & State $(\%)$ & Municipality $(\%)$ \\
\hline Very important & 15.0 & 33.6 \\
Quite important & 6.7 & 10.8 \\
Not important at all & 6.9 & 7.3 \\
This is not a source of income for us & 71.4 & 48.3 \\
Total & 100.0 & 100.0 \\
Total number of analysed cases $(N)$ & 2.028 & 2.248 \\
\hline
\end{tabular}

of the statement. In this sense, one factor is implicit in the question. To show the extent of such support, we present a frequency table with the answers to the question 'How important are the following sources of income for your organization's budget?' focusing on the state and municipalities.

The table shows that almost $50 \%$ of the Swedish CSOs do not receive any economic support from municipalities and over $70 \%$ do not receive any from the state. This shows that, based on an objective assessment of independence, a significant number of CSOs are independent of municipalities and the state when it comes to financial resources. Following the theoretical assumptions, we might expect them to be able, to engage in advocacy strategies without a compromise, and including voicing criticism of the state and municipal authorities. Even if we can imagine that organizations hold back their criticism for the purpose of not risking the possibility of accessing future economic support, we expect from both a theoretical and a logical point of view that these variables will have a significant influence on our dependent variable.

If we turn our attention to how many actually hold back their criticism, we find that very few Swedish CSOs choose to hold back their criticism of the state and municipalities (see Table 2). More than 90\% of the Swedish CSOs strongly disagreed with the statement and only $2.2 \%$ agreed or strongly agreed. Hence, a small minority of CSOs state that they make such a strategic choice. This is not surprising in view of the implication of such a statement for the organizations' self-image and the independent and

Table 2 Holding back criticism of the state and municipalities for the purpose of not risking their economic support

\begin{tabular}{lc}
\hline The organizations agree to the statement & Percentage \\
\hline Very much & 0.9 \\
Somewhat & 1.3 \\
Not very much & 7.0 \\
Not at all & 90.8 \\
Total & 100.0 \\
Total number of analysed cases $(N)$ & 2.384 \\
\hline
\end{tabular}


scrutinizing role CSOs are expected to play. Swedish CSOs are supposed to play an important role in the democratic system, and admitting that they are compromising their advocacy function in this way means a step away from the 'Swedish model'.

\section{What Makes Swedish CSOs Hold Back Criticism?}

To analyse the impact of and interplay between factors, we have conducted a series of binary logistic regression analyses to assess which factors may underpin the CSOs' strategic choice of holding back their criticism of the state and municipalities for the purpose of not risking their economic support.

The regression shows three different models, with each model introducing new independent variables. The three models mirror the three sets of factors that have been presented in the first part. For each model, we present the standard error (S.E.) and the odds ratios $(\operatorname{Exp}(B))$. Odds ratios higher than 1 show that the factor makes it more likely for CSOs to hold back their criticism compared with the reference category, while ratios lower than 1 show that the factor makes it less likely. The last row shows the level of explanatory power (Nagelkerke $R$ square) of the different models, which increases each time we add more factors. The first model explains about $23 \%$ of the variation in the dependent variable, while the third model explains slightly more than $32 \%$.

The first model supports the relevance of factors related to financial resource dependency. Such a correlation is, as explained before, also implicit in the statement underlying the dependent variable. organizations that perceive municipal economic support to be important for their survival are four and a half times more likely to hold back their criticism compared to CSOs that do not perceive such support to be important. Economic support from the state shows a slightly lower odds ratio. ${ }^{4}$ Public support's share of the CSOs budget has, however, no significant influence on our dependent variable as those CSOs for whom public support accounts for $1-50 \%$ or for more than $50 \%$ of the budget are not more likely to hold back their criticism. Also the share of public financing linked to specific assignments does not seem to have any particular effect on the propensity of CSOs to hold back their criticism. Note the consistent discrepancy in the effect between perceived importance and actual importance of public funding here, which corroborates the importance of making a distinction

\footnotetext{
4 The service fields include the following functions: education, social services, health and development/housing, while the expressive fields include culture/recreation, professional/unions, civic/advocacy and environment.
}

between subjective perception and observed importance. The perceived importance of other sources of income, including public funding from the EU, does not seem to affect the dependent variable in any significant way, suggesting that diversifying sources of funding does not decrease the chances for an organization to hold back criticism.

The significance of organizational factors also finds support based on our analyses in the second model. The fact that the CSOs provide services on behalf of public organizations seems to have an impact on their propensity of holding back their criticism. In fact, those CSOs that engage in service delivery are 3.3 times more likely to limit their advocacy function for the purpose of not risking the economic support from state and municipalities. The fact that dependency on public resources has a negative effect on advocacy is not surprising, as it was partly implicit in the dependent variable. It is, however, important to note that the results suggest that if such resources are tied to service delivery, the CSOs are even more likely to refrain from engaging in advocacy, based on a concern to ascertain continued financial support.

The second model also shows that CSOs that perceive themselves as service oriented are twice more likely to hold back their criticism compared to expressive-oriented CSOs. If we also interpret such orientations as organizational identities, it is reasonable to assume that CSOs that see themselves mostly as service producers might more easily compromise their advocacy function as this is not their primary function.

The third model supports the relevance of institutional factors. CSOs that perceive a high level of competition from other CSOs for public assignments are twice more likely to hold back criticism. This might be interpreted as the CSOs being more likely to hold back their criticism when other organizations are competing for the same resources, which makes their position vis-à-vis the state less stable and reliable. Being threatened by competition from private enterprises does, however, not seem to impact on their advocacy activities. The results also show that CSOs that perceive public support as being essential for their survival are more likely to hold back their criticism (2.4 odds ratio). The results might strengthen importance of resource dependency, as dependency might become even stronger when the very existence of the organization is at stake. These results show that institutional factors might play an important role for how CSOs exercise advocacy, possibly because some CSOs might perceive their possibility of mobilizing resources as being limited to public authorities. Even when this last set of variables is introduced, the other correlations remain significant (Table 3). 
Table 3 CSOs holding back criticism of state and municipality

\begin{tabular}{|c|c|c|c|c|c|c|}
\hline & \multicolumn{2}{|c|}{ Model 1} & \multicolumn{2}{|c|}{ Model 2} & \multicolumn{2}{|c|}{ Model 3} \\
\hline & SE & $\operatorname{Exp}(B)$ & SE & $\operatorname{Exp}(B)$ & SE & $\operatorname{Exp}(B)$ \\
\hline \multicolumn{7}{|l|}{ Financial resource dependency } \\
\hline \multicolumn{7}{|c|}{ Importance of different sources of resources for the NPOs budget } \\
\hline Member fees important & 0.338 & 1.008 & 0.374 & 1.589 & 0.390 & 1.731 \\
\hline Selling service and products important & 0.321 & $1.700^{(*)}$ & 0.337 & 1.607 & 0.349 & 1.310 \\
\hline Donations important & 0.322 & 1.215 & 0.336 & 1.094 & 0.349 & 1.082 \\
\hline Economic support from municipality important & 0.473 & $4.479 * *$ & 0.492 & $4.122 * *$ & 0.496 & $3.581 * *$ \\
\hline Economic support from state important & 0.352 & $2.947 * *$ & 0.364 & $3.071 * *$ & 0.378 & $3.041 * *$ \\
\hline Economic support from EU important & 0.442 & 1.315 & 0.458 & 1.486 & 0.481 & 1.110 \\
\hline \multicolumn{7}{|c|}{ Public financing as share of the budget of the NPOs ('no public financing' reference) } \\
\hline Public financing $1-50 \%$ of budget & 0.995 & 1.130 & 0.996 & 1.118 & 1.036 & 1.074 \\
\hline Public financing $51-100 \%$ of budget & 1.027 & 2.895 & 1.039 & 2.268 & 1.080 & 1.754 \\
\hline \multicolumn{7}{|c|}{ Share of public financing that is tied to specific purposes ('no public funding tied to specific purposes' reference) } \\
\hline $1-50 \%$ of financing tied to specific purposes & 0.888 & 1.427 & 0.897 & 1.192 & 0.950 & 1.123 \\
\hline $51-100 \%$ of financing tied to specific purposes & 0.886 & 1.548 & 0.899 & 1.129 & 0.947 & 0.998 \\
\hline \multicolumn{7}{|l|}{ Organizational factors } \\
\hline \multicolumn{7}{|l|}{ Service delivery } \\
\hline Organization provides service on behalf of public org. & & & 0.361 & $3.336 * * *$ & 0.384 & $2.407 * *$ \\
\hline \multicolumn{7}{|l|}{ Employed staff ('no employed staff' reference) } \\
\hline Less than 5 staff employed & & & 0.393 & 0.942 & 0.402 & 0.850 \\
\hline 5 or more staff employed & & & 0.480 & 0.917 & 0.505 & 0.772 \\
\hline \multicolumn{7}{|l|}{ ICNPO focus of activity ('expressive-oriented' ref.) } \\
\hline Service-oriented & & & 0.347 & $1.972^{*}$ & 0.360 & $2.142 *$ \\
\hline \multicolumn{7}{|l|}{ Institutional factors } \\
\hline \multicolumn{7}{|l|}{ Level of competition and survival } \\
\hline High comp. from other org. for public assignments & & & & & 0.372 & $2.006(*)$ \\
\hline Threatened by comp. from private enterprises & & & & & 0.495 & 2.039 \\
\hline Public assignments essential for the survival of the org. & & & & & 0.371 & $2.365^{*}$ \\
\hline Constant & 0.611 & 0.003 & 0.667 & 0.002 & 0.680 & 0.001 \\
\hline Observations & 1.392 & & 1.392 & & 1.392 & \\
\hline Nagelkerke $R$ square & 0.233 & & 0.280 & & 0.323 & \\
\hline
\end{tabular}

$(*)<10 \%$

$*<5 \%$

$* *<1 \%$

$* * *<0.1$

\section{Discussion}

The study set out to investigate whether and why CSOs hold back their criticism and to analyse the interplay between sets of factors, i.e. financial, organizational and institutional factors and how such factors relate to the choice of CSOs to refrain from criticizing government.

The article has shown that a small number of Swedish CSOs state that they are compromising their advocacy function by refraining from voicing criticism. The significance and implication of this result reflect the nature of the question and the context in which it is asked. As Swedish CSOs are expected the play the role of watchdogs, scrutinizing public authorities, accepting that the organization is holding back criticism is a break with social norms and general expectations. A positive reply to this statement can have implications for the organization's self-image, as it may suggest a failure to fulfil the role as a representative of citizens, some of whom are vulnerable and possibly excluded from public services. We suggest the extent of the phenomenon is difficult to estimate based on such a direct question as many organizations might find it difficult to 
agree to such a strong statement. Nevertheless, some are outspoken about holding back criticism and this might be seen as the tip of an iceberg of organizations that choose to compromise on the critical voice function in some way. This implies that the meaning of CSOs' holding back their criticism relates to the societal role CSOs play and can thus be seen as highly context dependent. Considering the relatively inclusive relations Swedish governments' have with CSOs, we would expect higher numbers of CSOs holding back their criticism in other countries, where the position of CSOs is not as clearly related to that of a watchdog.

The study has also widened our understanding of what explains this particular form of advocacy. Our analyses confirm the relevance of each of the three strands of factors identified in our literature review to why CSOs refrain from criticizing governments. The study contributes to the field of research that concern whether and how resource dependency affects advocacy. While some research suggests that dependency on public agencies for funding may present an incentive for organizations to use their voice (e.g. Child and Gronbjerg 2007; Mosley 2012, 2013a, b, c), our results suggest it is crucial to make an analytical distinction between objective versus perceived dependence. Our study shows that the forms of dependency that matters for an organization's choice of holding back criticism cannot only be measured by budgetary 'facts', e.g. the share of the budget that comes from public funding or the share of public funding that is linked to specific assignments. What appears of much greater significance for an analysis of what leads to advocacy being compromise is the perceived importance of the funding by the organization. A key argument of this article is hence that it is essential to distinguish if organizations perceive the relationship as characterized by dependence or not before drawing a conclusion regarding the impact of funding on advocacy strategy.

Change in advocacy strategies is, however, not only a matter of resource dependency but also organizational factors, such as being a provider of services on behalf of public authorities, and the organization's general service orientation. Furthermore, an institutional setting characterized by competition also appears to be of significance. This suggests an interplay between factors, with each factor reinforcing the others and together contributing to CSOs compromising with their advocacy function. While the analytical model is applied to the Swedish case, the model is not biased towards specific context characteristics and is therefore applicable to other contexts too. Although the historical relationship between CSOs and the Swedish welfare state may be specific, the changes that the Swedish welfare state is undergoing are similar to those in other countries and key aspects of these changes are captured through financial, organizational and institutional factors.
Also, the results prompt us to further explore how policies and institutional landscapes shape how voices can be expressed as well as whose voices are given opportunities to be heard. It is important to expand our understanding of how policies that invite participation of CSOs in funding arrangements, public contracts and delivery of welfare services may inadvertently lead to organizations constraining their expressive voice function, and/or exclude organizations that identify strongly with an expressive voice function, and who choose not to get involved in service delivery and subsequent access to arenas where they can represent their constituencies.

Refraining from criticism is an active choice based on the organization's own interpretations of the relevance of the public funding for the organizations' budget and based on organizational identity, needs and experiences. For example, organizations that align themselves with a service-oriented identity, that express a need for public assignments, and that perceive their environment as competitive, are more prone to hold back from criticizing public authorities. The fact that service provision as such is relevant suggests of course also isomorphic tendencies among CSOs. With the caveat that our method does not capture unintentional changes in advocacy as often implied in 'isomorphic changes', our results illustrate that foremost organizations make a strategic choice to hold back criticism.

Furthermore, our results have implications for how we theorize on advocacy strategies, in particular how theories can distinguish between change as a result of an active choice that reflect organizational agency, as the result of a rational choice, or the result of isomorphism. Much advocacy research has a quantitative bias, with a focus on factual variables and hence inadvertently treat organizations as rational (although see Garrow and Hasenfeld 2012; Onyx et al. 2010). Studies assume that organizations respond almost mechanically to internal and external factors that are 'objective'. Some researchers of social movements (e.g. Gamson and Meyer 1996; Benford and Snow 2000; Polletta and Jasper 2001) are critical to this approach, and for the purpose of understanding collective action, they include cognitive variables related to the way in which social movements and the organizations they spawn understand themselves and their environment. Concepts such as organizational identity, culture, framing and perceived opportunity structures are used to grasp more subjective dimensions of organizations. Resource dependence theory, the way it is often applied, does not necessarily reflect such felt, or constructed, dependence. Here, however, we emphasize that it is the perceived need of resources that informs activities which suggests that dependency, to some extent, is socially constructed. In this case, organizations frame their position vis-à-vis public 
authorities as one characterized by dependency and adjust their activities accordingly. Similarly, organizations that identify relations with other CSOs as characterized by competition frame their environment and their own position as volatile. Research that tries to capture the complex connections between states and CSOs by measuring tangibles thus needs to review their analytical assumptions and explore a perspective that distinguishes between the perceived value and nature of relationships and organizational characteristics, rather than only focusing on objective numbers that are assumed to represent the characteristics of a relationship in terms of dependence/ independence.

\section{Conclusion}

This article contributes to a growing field of research on CSOs and advocacy by addressing whether and why CSOs compromise with their advocacy function and hold back criticism against governments. Changes in advocacy strategies are often seen as an inadvertent consequence of, e.g. resource dependency, weak organizational capacities or institutional pressure. This article illustrates that holding back criticism is an active strategic choice made by CSOs, reflecting a climate that promotes service delivery, competition and strong financial ties between CSOs and public institutions. Identifying organizations that chose to hold back their criticism is crucial as they may represent a type of CSOs that is becoming more widespread. Similarly, identifying an institutional environment that promotes this type of organization is of importance. In the light of the 2008 European financial and political crisis and more pronounced neoliberal policy agendas, European governments have increasingly contracted out welfare services to either private-for-profit companies or different types of CSOs acting as service providers. At present, there is little evidence that this trend will cease and hence the prevalence of organizations choosing to hold back criticism is likely to gain in significance.

Further research on these topics is required as the results open up for further questions. Although we can establish that some organizations resort to a strategy that involves holding back criticism and hence compromise on their role as critical voice, its wider implications are not clear. While 'holding back criticism' against governments may suggest a challenge to the democratic function of CSOs in most liberal democracies, it may not imply that radical advocacy has been abandoned but potentially reframed according to new organizational and political circumstances where 'radical' is taking new forms (Onyx et al. 2010). In order to compensate for a compromise, CSOs might adopt more dynamic, flexible and diversified advocacy strategies that include a combination of confrontational/consensual activities and/or insider/outsider tactics depending on the issue at stake or the relation with the government at hand.

While these are challenging research tasks ahead, for CSOs it appears of key importance not to focus too much on the public grants and contracts per se. Although they have significance and might increase dependence on the state, for some organizations it seems reasonable to 'keep calm and carry on' with advocacy activities as before. It is not based on the amount of money that the state exercises most control and power, but based on how CSOs perceive the relevance of such money, that makes them dependent upon state authorities. It would, however, not be correct to state that dependency is 'all in your head'. We still have limited knowledge of how organizations perceive their environment and how they make up their mind about the best strategy for achieving their goals. Why do certain organizations feel threatened by competition while others do not? To what extent are these perceptions a mirror of endogenous and exogenous objective factors, or part of cognitive processes that might be unique for each organization? Either way, policy-makers who want to reconcile high levels of public funding for CSOs in a system of contracting-out services with an independent civil society that is able to exercise a critical voice function, should invest in creating an environment that fosters mutual trust and that downplays competitive features of the system. Otherwise, for some CSOs the strategic choice might be between avoiding public funding and assignments and compromising with advocacy.

Acknowledgements This research has been funded by the Swedish Research Council (Grant 2010-1678).

\section{Compliance with Ethical Standards}

Conflict of interest The authors declare that they have no conflict of interest.

Open Access This article is distributed under the terms of the Creative Commons Attribution 4.0 International License (http://crea tivecommons.org/licenses/by/4.0/), which permits unrestricted use, distribution, and reproduction in any medium, provided you give appropriate credit to the original author(s) and the source, provide a link to the Creative Commons license, and indicate if changes were made.

\section{References}

Agreement. (2008). Överenskommelsen mellan regeringen, idéburna organisationer inom det sociala området och Sveriges Kommuner och Landsting. Retrieved from http://overenskommelsen. se/wp-content/uploads/2015/03/Överenskommelsen.pdf.

Balassiano, K., \& Chandler, S. M. (2010). The emerging role of nonprofit associations in advocacy and public policy: Trends, 
issues, and prospects. Nonprofit and Voluntary Sector Quarterly, 39(5), 946-955. https://doi.org/10.1177/0899764009338963.

Benford, R., \& Snow, D. (2000). Framing processes and social movements: An overview and assessment. Annual Review of Sociology, 26, 611-639.

Beyers, J. (2004). Voice and access: Political practices of european interest associations. European Union Politics, 5(2), 211-240.

Binderkrantz, A. (2005). Interest group strategies: Navigating between privileged access and strategies of pressure. Political Studies, 53(4), 694-715.

Boris, E., \& Mosher-Williams, R. (1998). Nonprofit advocacy organizations: Assessing the definitions, classifications, and data. Nonprofit and Voluntary Sector Quarterly, 27(4), 488-506.

Chaves, M., Stephens, L., \& Galaskiewicz, J. (2004). Does government funding suppress nonprofits' political activity? American Sociological Review, 69(2), 292-316.

Child, C. D., \& Gronbjerg, K. A. (2007). Nonprofit advocacy organizations: Their characteristics and activities. Social Science Quarterly, 88(1), 259-281.

Danielson, A., Zetterberg, P. \& Amnå, E. (2009). Bidrag till vad?En kunskapsöversikt övereffekter och metoder rörande statliga bidrag till ideella organisationer. Rapport till Ungdomsstyrelsen.

Dür, A., \& Mateo, G. (2013). Gaining access or going public? Interest group strategies in five European countries. European Journal of Political Research, 52, 660-686.

Gamson, W. A., \& Meyer, D. S. (1996). Framing political opportunity. In D. McAdam, J. D. McCarthy, \& M. N. Zald (Eds.), Comparative perspectives on social movements: Political opportunities, mobilizing structures and cultural framings (pp. 275-290). Cambridge: Cambridge University Press.

Garrow, E. E., \& Hasenfeld, Y. (2012). Institutional logics, moral frames, and advocacy: Explaining the purpose of advocacy among nonprofit human-service organizations. Nonprofit and Voluntary Sector Quarterly. https://doi.org/10.1177/ 0899764012468061.

Hall, M., Millo, Y., \& Barman, E. (2015). Who and what really counts? Stakeholder prioritization and accounting for social value. Journal of Management Studies, 52(7), 907-934. https:// doi.org/10.1111/joms.12146.

Hartman, L. (Ed.). (2011). Konkurrensens konsekvenser-Vad händer med svensk välfärd. Stockholm: SNS.

Hasenfeld, Y., \& Garrow, E. E. (2012). Nonprofit human-service organizations, social rights, and advocacy in a neoliberal welfare state. Social Service Review, 86(2), 295-322.

Hermansson, J., Lund, A., Svensson, T., \& Öberg, P.-O. (1999). Avkorporatisering och lobbying. Official Reports of the Swedish Government SOU, 1999, 121.

Johansson, S. (2005). Ideella mål med offentliga medel_Förändrade förutsättningar för ideell välfärd. Stockholm: Sober förlag.

Johansson, H., Arvidson, M., \& Johansson, S. (2015). Welfare mix as a contested terrain: Political positions on government-non-profit relations at national and local levels in a social democratic welfare state. Voluntas, 26(5), 1601-1619. https://doi.org/10. 1007/s11266-015-9580-4.

Lundström, T., \& Svedberg, L. (2003). The voluntary sector in a social democratic welfare state-The case of Sweden. Journal of Social Policy, 32, 217-238.

Lundström, T., \& Wijkström, F. (1995). Från röst till service?-den svenska ideella sektorn i förändring. Sköndal: Sköndalsinstitutet.

Lundström, T., \& Wijkström, F. (1997). The non-profit sector in Sweden. Manchester: Manchester University Press.

MacIndoe, H., \& Barman, E. (2013). How organizational stakeholders shape performance measurement in nonprofits. Nonprofit and Voluntary Sector Quarterly, 42(4), 716-738. https://doi.org/10. 1177/0899764012444351.
Mosley, J. (2013a). Recognizing new opportunities: Reconceptualizing policy advocacy in everyday organizational practice. Social Work, 58(3), 231-239. https://doi.org/10.1093/sw/swt020.

Mosley, J. E. (2011). Institutionalization, privatization, and political opportunity: What tactical choices reveal about the policy advocacy of human service nonprofits. Nonprofit and Voluntary Sector Quarterly, 40(3), 435-457. https://doi.org/10.1177/ 0899764009346335.

Mosley, J. E. (2012). Keeping the lights on: How government funding concerns drive the advocacy agendas of nonprofit homeless service providers. Journal of Public Administration Research and Theory, 22(4), 841-866. https://doi.org/10.1093/jopart/ mus003.

Mosley, J. E. (2013b). Organizational resources and environmental incentives: Understanding the policy advocacy involvement of human service nonprofits. Social Service Review, 84(1), 57-76.

Mosley, J. E. (2013c). The beliefs of homeless service managers about policy advocacy: Definitions, legal understanding, and motivations to participate. Administration in Social Work, 37(1), 73-89. https://doi.org/10.1080/03643107.2012.656221.

Mosley, J. E., Maronick, M. P., \& Katz, H. (2012). How organizational characteristics affect the adaptive tactics used by human service nonprofit managers confronting financial uncertainty. Nonprofit Management and Leadership, 22(3), 281-303. https:// doi.org/10.1002/nml.

Neumayr, M., Schneider, U., \& Meyer, M. (2015). Public funding and its impact on nonprofit advocacy. Nonprofit and Voluntary Sector Quarterly, 44(2), 297-318. https://doi.org/10.1177/ 0899764013513350.

Nicholson-Crotty, J. (2007). Politics, policy, and the motivations for advocacy in nonprofit reproductive health and family planning providers. Nonprofit and Voluntary Sector Quarterly, 36(1), 5-21. https://doi.org/10.1177/0899764006291778.

Olsson, L. E., Nordfeldt, M., Larsson, O., \& Kendall, J. (2009). Sweden: When strong third sector historical roots meet EU policy processes. In J. Kendall (Ed.), Handbook on third sector policy in Europe-Multi-level processes and organized civil society. Cheltenham: Edward Elgar Publishing.

Onyx, J., Armitage, L., Dalton, B., Melville, R., Casey, J., \& Banks, R. (2010). Advocacy with gloves on: The "Manners" of strategy used by some third sector organizations undertaking advocacy in NSW and Queensland. VOLUNTAS: International Journal of Voluntary and Nonprofit Organizations, 21(1), 41-61. https:// doi.org/10.1007/s11266-009-9106-z.

Pache, A.-C., \& Santos, F. (2010). When worlds collide: The internal dynamics of organizational responses to conflicting institutional demands. Academy of Management Review, 35(3), 455-476.

Pfeffer, J., \& Salancik, G. R. (1978). The external control of organizations. A resource dependence perspective. Stanford, California: Stanford Business Classics.

Polletta, F., \& Jasper, J. (2001). Collective identity and social movements. Annual Review of Sociology, 27, 283-305.

Salamon, M. L., Sokolowski, S. W., \& List, R. (2004). Global civil society-An overview. In M. L. Salamon (Ed.), Global civil society-dimensions of the nonprofit sector. Kumarian: Bloomfield, Conn.

Scaramuzzino, R. \& Wennerhag, M. (2013). Influencing politics, politicians and bureaucrats: Explaining differences between Swedish CSOs' strategies to promote political and social change. Paper presented at 7th ECPR General Conference Sciences Po, Bordeaux, 4-7 September 2013

SCB. (2010). Det civila samhället 2010: Ett regeringsuppdrag med undersökningar från Statistiska centralbyrån $=$ [The civil society 2010: An assignment from the government with surveys from Statistics Sweden]. Örebro: Statistiska centralbyrån (SCB). 
Schmid, H., Bar, M., \& Nirel, R. (2008). Advocacy activities in nonprofit human service organizations: Implications for policy. Nonprofit and Voluntary Sector Quarterly, 37(4), 581-602. https://doi.org/10.1177/0899764007312666.

Scott, W. R., Deschenes, S., Hopkins, K., Newman, A., \& McLaughlin, M. (2006). Advocacy organizations and the field of youth services: Ongoing efforts to restructure a field. Nonprofit and Voluntary Sector Quarterly, 35(4), 691-714. https://doi.org/10.1177/0899764006289772.

Snavely, K., \& Desai, U. (2000). Mapping local governmentnongovernmental organization interactions: A conceptual framework. Journal of Public Administration Research and Theory, 11(2), 245-264. Retrieved from http://jpart.oxfordjournals.org/ cgi/content/abstract/11/2/245.

Svallfors, S. (2015) Politics as organized combat. MPlfG Discussion Paper 15/2. Retrieved from www.mpifg.de/pu/mpifg_dp/dp15-2. pdf.
Trägårdh, L. (2010). Rethinking the Nordic welfare state through a neo-Hegelian theory of state and civil society. Journal of Political Ideologies, 15(3), 227-239. https://doi.org/10.1080/ 13569317.2010.513853.

Verschuere, B., \& De Corte, J. (2014). The impact of public resource dependence on the autonomy of NPOs in their strategic decision making. Nonprofit and Voluntary Sector Quarterly, 43(2), 293-313. https://doi.org/10.1177/0899764012462072.

Verschuere, B., \& De Corte, J. (2015). Nonprofit advocacy under a third-party government regime: Cooperation or conflict? VOLUNTAS: International Journal of Voluntary and Nonprofit Organizations, 26(1), 222-241. https://doi.org/10.1007/s11266013-9427-9.

Wijkström, F., \& Einarsson, T. (2006). Från nationalstat till näringsliv?: Det civila samhällets organisationsliv i förändring. Stockholm: Ekonomiska forskningsinstitutet (EFI), Handelshögskolan i Stockholm. 